\title{
Influence of Convolution Kernel and Beam-Hardening Effect on the Assessment of Trabecular Bone Mineral Density Using Quantitative Computed Tomography
}

\author{
D. V. Ivanov, I. V. Kirillova, L. Yu. Kossovich, L. V. Bessonov, \\ A. V. Petraikin, A. V. Dol, E. S. Ahmad, S. P. Morozov, \\ A. V. Vladzymyrskyy, K. A. Sergunova, A. V. Kharlamov
}

Dmitriy V. Ivanov, https://orcid.org/0000-0003-1640-6091, Saratov State University, 83 Astrakhanskaya St., Saratov 410012, Russia, ivanovdv@gmail.com

Irina V. Kirillova, https://orcid.org/0000-0001-8053-3680, Saratov State University, 83 Astrakhanskaya St., Saratov 410012, Russia, nano-bio@info.sgu.ru

Leonid Yu. Kossovich, https://orcid.org/0000-0002-4775-7348, Saratov State University, 83 Astrakhanskaya St., Saratov 410012, Russia, president@info.sgu.ru

Leonid V. Bessonov, https://orcid.org/0000-0002-5636-1644, Saratov State University, 83 Astrakhanskaya St., Saratov 410012, Russia, bessonov@sgu.ru

Alexey V. Petraikin, https://orcid.org/0000-0003-1694-4682, State Budget-Funded Health Care Institution of the City of Moscow "Research and Practical Clinical Center for Diagnostics and Telemedicine Technologies of Moscow Health Care Department", 28-1 Srednyaya Kalitnikovskaya St., Moscow 109029, Russia, alexeypetraikin@gmail.com

Aleksandr V. Dol, https://orcid.org/0000-0001-5842-1615, Saratov State University, 83 Astrakhanskaya St., Saratov 410012, Russia, dzero@pisem.net

Ekaterina S. Ahmad, https://orcid.org/0000-0002-4293-2514, State Budget-Funded Health Care Institution of the City of Moscow "Research and Practical Clinical Center for Diagnostics and Telemedicine Technologies of Moscow Health Care Department", 28-1 Srednyaya Kalitnikovskaya St., Moscow 109029, Russia, e.ahmad@npcmr.ru

Sergey P. Morozov, https://orcid.org/0000-0001-6545-6170, State Budget-Funded Health Care Institution of the City of Moscow "Research and Practical Clinical Center for Diagnostics and Telemedicine Technologies of Moscow Health Care Department", 28-1 Srednyaya Kalitnikovskaya St., Moscow 109029, Russia, npcmr@zdrav.mos.ru

Anton V. Vladzymyrskyy, https://orcid.org/0000-0002-2990-7736, State Budget-Funded Health Care Institution of the City of Moscow "Research and Practical Clinical Center for Diagnostics and Telemedicine Technologies of Moscow Health Care Department", 28-1 Srednyaya Kalitnikovskaya St., Moscow 109029, Russia, info@npcmr.ru

Kristina A. Sergunova, https://orcid.org/0000-0002- 9596-7278, State Budget-Funded Health Care Institution of the City of Moscow "Research and Practical Clinical Center for Diagnostics and Telemedicine Technologies of Moscow Health Care Department", 28-1 Srednyaya Kalitnikovskaya St., Moscow 109029, Russia, sergunova@rpcmr.org.ru

Aleksandr V. Kharlamov, https://orcid.org/0000-0002-1709-6518, Saratov State University, 83 Astrakhanskaya St., Saratov 410012, Russia, harlamovav@info.sgu.ru

Quantitative computed tomography along with densitometry is used to assess mineral density and strength of bone tissue. Raw data obtained by computed tomography are converted by software using convolution kernels. It is known that the use of convolution kernels can significantly change tissue density, which is measured in Hounsfield units. The beam-hardening effect is described in literature: when $\mathrm{x}$-ray passes through an object, the absorption of lower-energy $\mathrm{x}$-ray photons occurs. Therefore, scanning objects "in the air" without surrounding soft tissues of the human body gives distorted Hounsfield units relative to their real values. This work is aimed at assessing

(c) D. V. Ivanov, I. V. Kirillova, L. Yu. Kossovich, L. V. Bessonov, A. V. Petraikin, A. V. Dol,

E. S. Ahmad, S. P. Morozov, A. V. Vladzymyrskyy, K. A. Sergunova, A. V. Kharlamov, 2020 
the effect of various convolution kernels, beam-hardening effect, as well as other CT scanner settings for Hounsfield units. In this work, we studied samples of trabecular bone tissue of the femoral heads and calibrated samples of an aqueous solution of dipotassium hydrogen phosphate with known mineral density. Trabecular bone tissue samples of the femoral heads and calibrated samples of an aqueous solution of dipotassium hydrogen phosphate with known mineral density were scanned on Toshiba Aquilion 64 scanner. The samples were scanned in various modes: at different tube currents, "in the air" and inside the calibration phantom. The resulting images processed by the FC17 and FC03 convolution kernels were analyzed. It was shown that tube current magnitude practically does not affect the Hounsfield units. Different convolution kernels demonstrate significantly different Hounsfield units when scanning the same samples "in the air". It has been confirmed that the beam-hardening effect significantly affects the Hounsfield units and should be considered when evaluating bone mineral density. No differences were found in measurements "in the air' and in the phantom at a significance level of 5\% for the FC03 kernel, which confirms the fact that FC03 is intended to correct the beam-hardening effect. An ambiguous relationship was noted between the Hounsfield units and the mineral density for low-density samples when scanned with the FC03 kernel. FC17 kernel, in comparison with $\mathrm{FC03}$, is considered more preferable and suitable for assessing bone mineral density. However, pre-calibration with phantom is required for a wide range of preset mineral densities. Regression dependencies were obtained for recalculation of Hounsfield units from experiments "in the air" to Hounsfield units of the same samples scanned in surrounding tissues (in the phantom).

Keywords: computed tomography, quantitative computed tomography, bone mineral density, Hounsfield unit, convolution kernel.

Received: 15.12.2019 / Accepted: 22.01.2020 / Published: 01.06.2020

This is an open access article distributed under the terms of Creative Commons Attribution License (CC-BY 4.0)

DOI: https://doi.org/10.18500/1816-9791-2020-20-2-205-219

\section{INTRODUCTION}

Quantitative computed tomography (QCT) along with dual energy x-ray absorptiometry (DXA) are used to assess mineral density and strength of bone tissue. According to computed tomography (Hounsfield units), bone density is known to strongly correlate with volume mineral density $[1,2]$ as well as with the mechanical strength of bone tissue $[3,4]$. Asynchronous QCT is the most advanced technology that allows obtaining data on the bone mineral density (BMD) of patients without simultaneously scanning a calibration phantom, conducting periodic calibrations of an asynchronous phantom $[5,6]$.

When performing computed tomography (CT), the projections of the scanned object (synograms) using the reconstruction kernel are converted into a series of images. The result is parallel slices located at equal distances from each other. Further, these data are converted by means of convolution kernels. Convolution kernels are used to achieve greater visual expressiveness of objects on the tomogram. In other words, they are needed for a more detailed and informative presentation of objects of a certain density range. For example, there are kernels designed for soft tissue and kernels for bone tissue [7]. The use of convolution kernels can significantly change the Hounsfield units (HU) of tissues relative to their initial values [8]. Different convolution kernels change HU differently $[4,7,9]$. Therefore, the problem of choosing an appropriate convolution kernel when performing QCT is nontrivial. Manufacturers of CT do not allow to upload raw data that has not been processed using convolution kernels. Moreover, mathematical 
descriptions of such kernels are not available in the public literature.

According to the literature, not only the type of convolution kernel affects the absolute values of the Hounsfield units (HU). Tube voltage, table height and field of view (FOV) also have a significant impact on quantitative scan results [10]. It is also known that different CT scanners give different Hounsfield units for the same objects, which complicates the problem of calculating the BMD [10].

The beam-hardening effect is described in literature: when x-ray passes through an object, the absorption of lower-energy x-ray photons occurs [11]. Therefore, when scanning bones not surrounded by soft tissues of the human body ("in the air"), HU are overestimated [12]. This effect can be avoided by scanning objects in special phantoms that simulate human body. There are computational algorithms that allow one to eliminate the beam-hardening effect. Such algorithms are implemented by manufacturers of CT scanners into convolution kernels. However, the effectiveness of these algorithms is not well understood, and their mathematical description is not presented in the literature.

The domestic and foreign scientific groups and companies develop and use various phantoms for calibrating CT scanners $[4,13,14]$. Phantoms are special devices that simulate soft tissues of the human body. Special calibrated samples with known mineral density are placed inside these phantoms. Scanning such phantoms allows one to develop a relationship between the Hounsfield unit and mineral density of the scanned object.

The objectives of this work were:

- to illustrate the work of convolution matrices (the simplest version of the convolution kernel) on the example of spine CT images;

- to assess the influence of various convolution kernels, the beam-hardening effect, as well as some other settings of CT scanners on HU of the femoral heads trabecular bone tissue and calibrated samples of an aqueous solution of dipotassium hydrogen phosphate [14] with known mineral density.

\section{MATERIALS AND METHODS}

\subsection{Threshold filters and convolution kernels to CT images application}

Within the framework of this section, we will consider CT images as an $N \times M$ matrix

$$
I=\left(\begin{array}{ccc}
i(1,1) & \ldots & i(N, 1) \\
\vdots & \ddots & \vdots \\
i(1, M) & \ldots & i(N, M)
\end{array}\right)
$$

that corresponds to the horizontal $(\mathrm{N})$ and vertical $(M)$ image dimensions in pixels.

The numbers $i(x, y)$ at the nodes of the matrix represent the number of the shades of gray color from 0 to a certain maximum value (corresponding to the pixel of the CT image), where 0 corresponds to black and the maximum value corresponds to white.

This paper illustrates and evaluates the effect of two types of image transformations: the "threshold cutoff" and the "detection of boundaries".

The simplest method is "threshold cutoff". With this conversion, image sections that do not correspond to a given range of interest are replaced with some fixed color (for example, black).

$$
i_{\text {new }}(x, y)= \begin{cases}i(x, y), & t_{1}<i(x, y)<t_{2}, \\ 0, & \text { otherwise }\end{cases}
$$

where $t_{1}$ and $t_{2}$ are the left and right boundaries of the range of interest (in terms of tissue density). 
Using this transformation, all areas of the CT image, except those that have the density of interest (for example, bone tissue), can be excluded from consideration

A more complex example is the boundary detection transformation. This is a processing aimed at identifying image points in the vicinity of which a change in brightness occurs. This algorithm is most effective in cases where the brightness change in the figure is insignificant, so the visualization of the boundaries of the objects is improved due to the conversion.

As a rule, a discrete $2 \mathrm{D}$ convolution with a kernel specified by matrix is used for this processing. The operation is indicated as follows: $I_{\text {new }}=k * I$, where $k$ is a matrix with dimensions of $(2 a+1) x(2 b+1)$, where $a$ and $b$ are positive integers. Such convolution operation is defined as follows:

$$
i_{n e w}(x, y)=\sum_{u=-a}^{a} \sum_{v=-b}^{b} k(u, v) * i(x-u, y-v) .
$$

Each pixel of the new image is obtained from the corresponding pixel of the original image, taking into account its neighboring pixels, which are no more than $a$ pixels along the $O x$ axis and no more than $b$ pixels along the $O y$ axis.

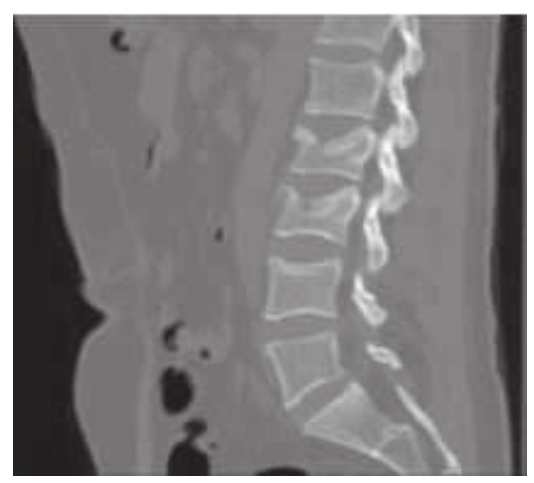

Fig. 1. Sagittal CT scan of the lumbar spine

This paper shows the application of convolution matrices $k_{1}, k_{2}, k_{3}$ to the original image (Fig. 1) of the patient's spine CT

$$
\begin{gathered}
k_{1}=\left(\begin{array}{ccc}
-1 & -1 & -1 \\
-1 & 8 & -1 \\
-1 & -1 & -1
\end{array}\right), \quad k_{2}=\left(\begin{array}{ccc}
0 & -1 & 0 \\
-1 & 6 & -1 \\
0 & -1 & 0
\end{array}\right) \\
k_{3}=\left(\begin{array}{ccc}
-2 & -1 & 0 \\
-1 & 1 & 1 \\
0 & 1 & 2
\end{array}\right) .
\end{gathered}
$$

The source image is shown in Fig. 1 was processed using an application written in Python. In the software, the image was presented in matrix form, which was then convoluted with the kernels given by the matrices $k_{1}, k_{2}, k_{3}$. The original images were obtained by exporting DICOM images to a PNG image containing grayscale from 0 to 256 . As a result of the software, three processed PNG images were obtained from the source file.

\subsection{Experiments on $\mathrm{CT}$ scanner}

Samples of trabecular bone tissue of the femoral heads, taken during surgical treatment of arthrosis of the hip joints of NIITON SSMU patients, were scanned on a Toshiba Aquilion 64 CT scanner. The bone tissue transfer of NIITON SSMU patients was approved by the ethics committee and was carried out under the agreement on the implementation of the project approved by Russian Foundation for Advanced Research Projects in the Defense Industry. Calibrated samples of an aqueous solution of dipotassium hydrogen phosphate with known mineral density were also scanned on CT scanner.

Samples of the trabecular bone and an aqueous solution of dipotassium hydrogen phosphate $\left(\mathrm{K}_{2} \mathrm{HPO}_{4}\right)$ were scanned on a CT scanner table ("in the air") and in the calibration phantom PHK (PHantom Kalium). PHK is a special test object, which is a 
cylinder filled with liquid with the ability to simulate the subcutaneous fat layer of a human [14]. Samples of $\mathrm{K}_{2} \mathrm{HPO}_{4}$ and the phantom were provided by "Scientific and Practical Clinical Center for Diagnostics and Telemedicine Technologies" of the Moscow Department of Health.

Five samples of trabecular bone tissue and eight samples of $\mathrm{K}_{2} \mathrm{HPO}_{4}$ simulating a specific BMD were scanned. There were four cylindrical specimens with mineral density $50 \mathrm{mg} / \mathrm{sm}^{3}, 100 \mathrm{mg} / \mathrm{sm}^{3}, 150 \mathrm{mg} / \mathrm{sm}^{3}$ and $200 \mathrm{mg} / \mathrm{sm}^{3}$ simulating trabecular bone and four hexahedral samples with mineral density $250 \mathrm{mg} / \mathrm{sm}^{3}, 350 \mathrm{mg} / \mathrm{sm}^{3}, 450 \mathrm{mg} / \mathrm{sm}^{3}$ and $550 \mathrm{mg} / \mathrm{sm}^{3}$ simulating cortical bone.

Before scanning, each trabecular bone tissue sample was wrapped in a thin layer of plastic film so that water could not enter the bone tissue and could not change its density, and also so that the bone tissue could not dry in the air. Circular thin plastic plates with a low X-ray density and a thickness of $4 \mathrm{~mm}$ were placed between the trabecular bone samples during scanning in the phantom. Scanned samples were installed in the center of the phantom using a retaining frame. The phantom was filled with deionized water. Figure 2 shows the samples on the table of a CT scanner and "in phantom".

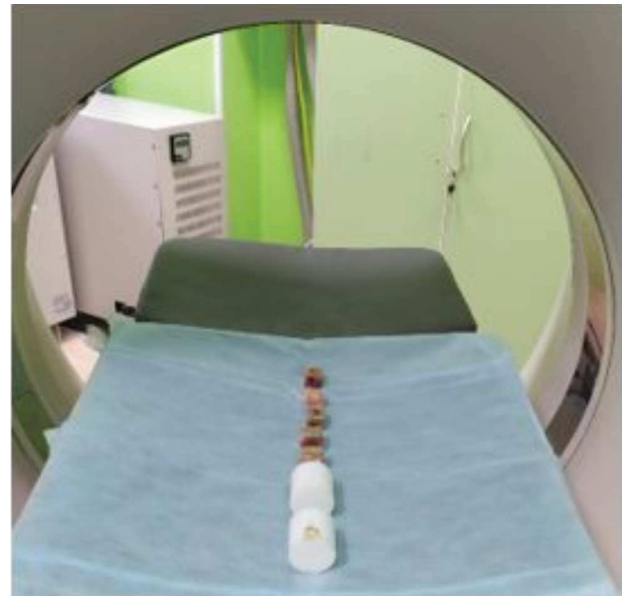

$a$

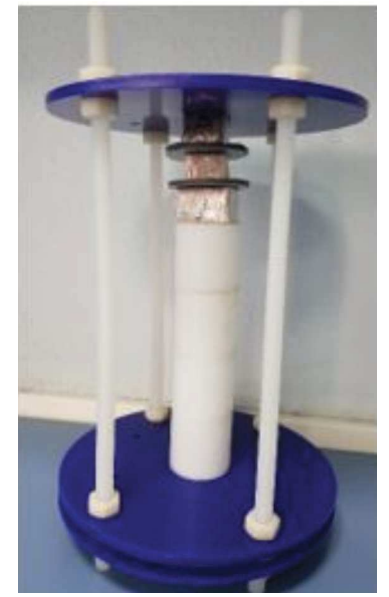

$b$

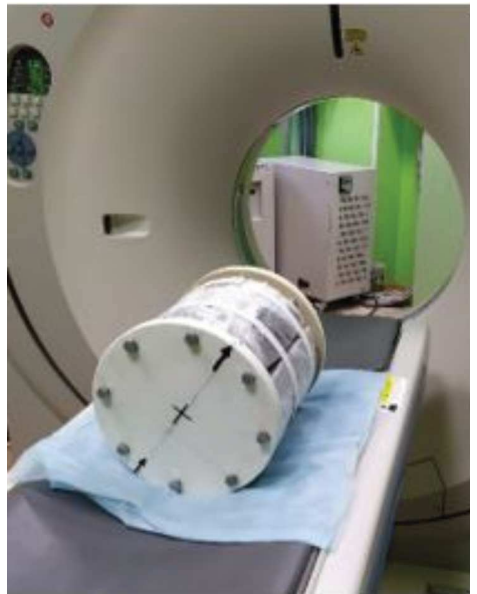

C

Fig. 2. Samples before scanning in CT scanner: $a-$ on the table of the CT scanner, "in the air"; $b$ - in the retaining frame of the phantom PHK; $c$ - on the table of the CT scanner inside the phantom PHK filled with water, "in phantom"

Scanning of the samples was carried out in various modes (Table 1). Each scan was repeated three times. The table of the CT scanner was fixed in such a position that the scanned samples were located in the center of the aperture of the CT scanner.

Table 1

Investigated CT scan modes and settings

\begin{tabular}{|c|c|c|c|c|c|c|}
\hline Scanning modes & \multicolumn{4}{|c|}{ "In the Air" } & \multicolumn{2}{|c|}{ "In phantom" } \\
\hline Voltage & \multicolumn{6}{|c|}{$120 \mathrm{kV}$} \\
\hline Tube current & \multicolumn{2}{|c|}{$40 \mathrm{~mA}$} & \multicolumn{2}{|c|}{$300 \mathrm{~mA}$} & \multicolumn{2}{|c|}{$300 \mathrm{~mA}$} \\
\hline Convolution kernel & FC17 & FC03 & FC17 & FC03 & $\mathrm{FC} 17$ & FC03 \\
\hline
\end{tabular}

Slice thickness in each scan was $1 \mathrm{~mm}$. The HU were analyzed using RadiAnt DICOM Viewer 5.0.1. For each sample and each scanning mode, average HU and standard deviation were obtained. 
Figure 3 shows the region of interest (circles or ellipses) over which $\mathrm{HU}$ in slices of scanned samples were averaged; a standard tool Region-Of-Interest of RadiAnt DICOM Viewer 5.0.1 was used.

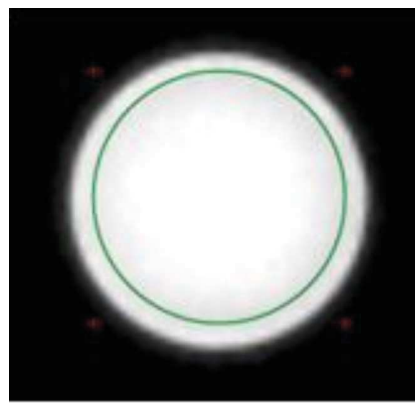

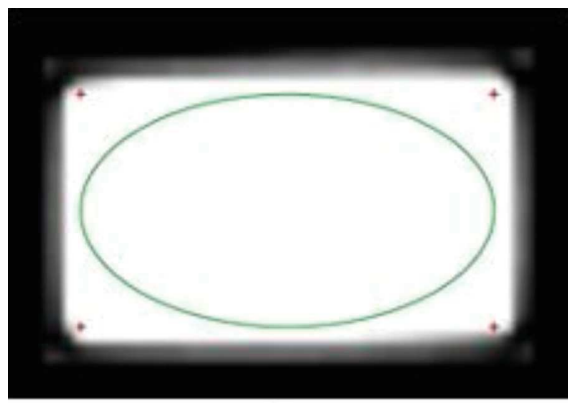

$b$

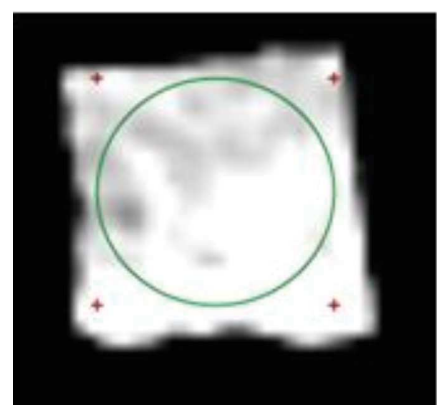

$C$

Fig. 3. Areas of interest: $a$ - cylindrical sample of an aqueous K2HPO4 solution; $b$ - a hexahedral sample of an aqueous $\mathrm{K}_{2} \mathrm{HPO}_{4}$ solution; $c$ - trabecular bone sample

For each sample, from four to ten values of the average cross-sectional numbers of HU were obtained, which were then converted to the average HU for each sample.

Statistical processing $[15,16]$ of the results was performed in Microsoft Excel.

\section{RESULTS}

\subsection{Convolution matrices application}

The new image containing only the boundaries of the vertebrae and some other objects (Fig. 4, a) was obtained after applying the convolution kernel $k_{1}(1)$ to the matrix of the original image in Fig. 1.

The new image containing only the boundaries of the vertebrae and some other objects (Fig. 4, b) was obtained after applying the convolution kernel $k_{2}(1)$ to the matrix of the original image in Fig. 1.

The new image containing only the boundaries of the vertebrae and some other objects (Fig. 4, c) was obtained after applying the convolution kernel $k_{3}(1)$ to the matrix of the original image in Fig. 1.

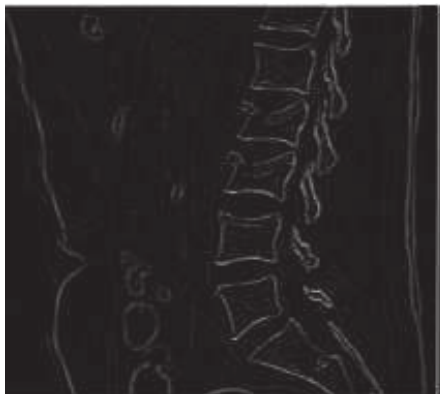

$a$

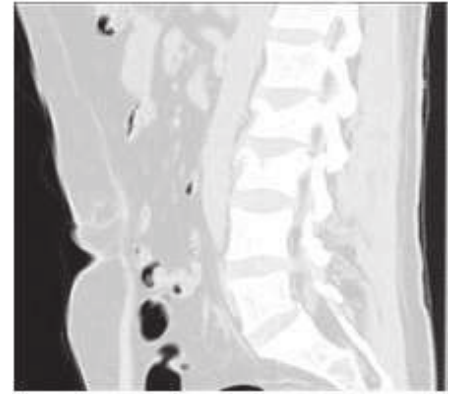

$b$

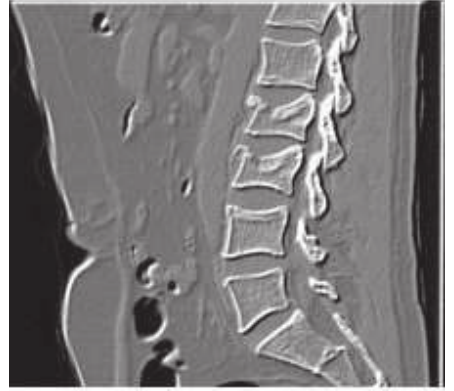

$c$

Fig. 4. Sagittal CT scan of the lumbar spine after convolution kernels $k_{1}(a), k_{2}(b)$ and $k_{3}(c)$ application

\subsection{Experiments in CT scanner}

Mean HU values of $\mathrm{HU}$ and standard deviation (SD) for each trabecular bone or $\mathrm{K}_{2} \mathrm{HPO}_{4}$ sample were obtained (Tables 2 and 3) with a series of CT scans using various scanning modes. 
Table 2

Mean $\mathrm{HU}$ and SD for three experiments for calibrated $\mathrm{K}_{2} \mathrm{HPO}_{4}$ samples at various scanning modes

\begin{tabular}{|c|c|c|c|c|c|c|c|c|c|c|c|c|}
\hline \multirow{4}{*}{$\begin{array}{l}\text { Volume } \\
\text { mineral } \\
\text { density, } \\
\mathrm{mg} / \mathrm{sm}^{3}\end{array}$} & \multicolumn{8}{|c|}{ "In the Air" } & \multirow{2}{*}{\multicolumn{4}{|c|}{ "In phantom" }} \\
\hline & \multicolumn{4}{|c|}{$40 \mathrm{~mA}$} & \multicolumn{4}{|c|}{$300 \mathrm{~mA}$} & & & & \\
\hline & \multicolumn{2}{|c|}{ FC17 } & \multicolumn{2}{|c|}{ FC03 } & \multicolumn{2}{|c|}{ FC17 } & \multicolumn{2}{|c|}{ FC03 } & \multicolumn{2}{|c|}{ FC17 } & \multicolumn{2}{|c|}{ FC03 } \\
\hline & Mean & SD & Mean & SD & Mean & SD & Mean & SD & Mean & SD & Mean & SD \\
\hline \multirow{3}{*}{550} & 983.1 & 28.9 & 760.3 & 13.9 & 986.3 & 29.6 & 762.1 & 14.3 & 687.0 & 14.7 & 705.7 & 12.0 \\
\hline & 984.9 & 29.6 & 760.3 & 13.9 & 984.7 & 28.7 & 762.4 & 13.6 & 686.8 & 14.0 & 705.8 & 12.3 \\
\hline & 984.4 & 29.4 & 760.0 & 14.8 & 985.4 & 29.6 & 760.1 & 14.7 & 686.8 & 13.8 & 705.7 & 12.7 \\
\hline \multirow{3}{*}{450} & 834.8 & 23.1 & 613.0 & 14.4 & 837.4 & 24.0 & 612.6 & 15.4 & 572.8 & 12.4 & 583.4 & 11.4 \\
\hline & 836.4 & 25.0 & 611.1 & 15.4 & 836.4 & 24.3 & 612.6 & 15.3 & 574.7 & 12.8 & 585.2 & 11.5 \\
\hline & 836.0 & 24.8 & 612.6 & 14.6 & 837.9 & 25.5 & 610.8 & 16.1 & 574.0 & 12.4 & 584.6 & 11.0 \\
\hline \multirow{3}{*}{350} & 679.9 & 19.3 & 458.5 & 16.1 & 679.8 & 18.3 & 459.8 & 15.6 & 454.7 & 10.7 & 459.0 & 10.1 \\
\hline & 678.9 & 18.6 & 458.3 & 16.0 & 679.4 & 18.0 & 459.9 & 15.4 & 443.0 & 11.1 & 446.9 & 10.6 \\
\hline & 680.4 & 21.1 & 456.0 & 18.6 & 680.9 & 20.1 & 458.4 & 16.0 & 455.6 & 11.1 & 459.3 & 10.6 \\
\hline \multirow{3}{*}{250} & 513.0 & 13.3 & 300.9 & 15.0 & 513.0 & 12.3 & 302.5 & 14.3 & 331.0 & 10.3 & 321.0 & 11.0 \\
\hline & 513.4 & 13.3 & 301.7 & 14.6 & 512.6 & 12.1 & 302.4 & 14.1 & 331.2 & 10.3 & 320.3 & 11.0 \\
\hline & 512.7 & 13.0 & 301.3 & 15.0 & 513.9 & 13.4 & 300.3 & 15.3 & 331.3 & 10.1 & 320.6 & 11.0 \\
\hline \multirow{3}{*}{200} & 421.1 & 11.3 & 226.1 & 20.1 & 423.0 & 10.8 & 229.2 & 19.4 & 272.2 & 8.2 & 259.6 & 8.2 \\
\hline & 421.6 & 10.8 & 227.0 & 19.8 & 422.6 & 10.8 & 228.6 & 19.4 & 271.8 & 8.4 & 259.2 & 8.2 \\
\hline & 422.2 & 11.4 & 226.0 & 20.8 & 426.2 & 13.2 & 227.2 & 20.6 & 271.8 & 8.6 & 259.4 & 8.6 \\
\hline \multirow{3}{*}{150} & 334.2 & 8.2 & 145.2 & 17.4 & 336.4 & 9.2 & 144.6 & 18.4 & 206.4 & 7.8 & 196.8 & 8.0 \\
\hline & 334.0 & 8.4 & 145.2 & 17.4 & 336.2 & 8.6 & 145.2 & 18.4 & 206.4 & 8.2 & 196.6 & 8.2 \\
\hline & 335.4 & 9.6 & 143.2 & 18.6 & 336.6 & 9.2 & 144.0 & 18.2 & 206.8 & 8.4 & 196.6 & 8.4 \\
\hline \multirow{3}{*}{100} & 237.0 & 6.0 & 204.8 & 5.2 & 238.6 & 5.6 & 206.4 & 4.2 & 134.6 & 7.6 & 128.6 & 8.0 \\
\hline & 236.8 & 6.2 & 205.0 & 5.2 & 238.0 & 5.6 & 205.6 & 4.0 & 134.8 & 8.0 & 128.2 & 8.0 \\
\hline & 237.4 & 6.2 & 205.6 & 5.4 & 238.2 & 5.6 & 206.0 & 4.2 & 134.4 & 7.8 & 127.8 & 8.0 \\
\hline \multirow{3}{*}{50} & 139.0 & 4.0 & 108.4 & 3.0 & 139.2 & 3.2 & 108.8 & 2.2 & 63.2 & 8.0 & 60.6 & 8.0 \\
\hline & 138.8 & 4.0 & 108.4 & 3.0 & 139.4 & 2.8 & 109.0 & 2.0 & 63.4 & 7.6 & 60.6 & 8.0 \\
\hline & 138.6 & 4.0 & 108.6 & 3.4 & 139.4 & 3.2 & 108.4 & 2.2 & 63.2 & 8.0 & 60.4 & 8.0 \\
\hline
\end{tabular}

Table 3

Mean HU and SD for three experiments for trabecular bone samples at various scanning modes

\begin{tabular}{|c|c|c|c|c|c|c|c|c|}
\hline \multirow{3}{*}{ Sample No } & \multicolumn{4}{|c|}{ "In the Air" } & \multicolumn{4}{c|}{ "In phantom" } \\
\cline { 2 - 9 } & \multicolumn{3}{|c|}{$300 \mathrm{~mA}$} & \multicolumn{3}{c|}{$300 \mathrm{~mA}$} \\
\cline { 2 - 9 } & \multicolumn{2}{|c|}{ FC17 } & \multicolumn{2}{|c|}{ FC03 } & \multicolumn{2}{c|}{ FC17 } & \multicolumn{2}{c|}{ FC03 } \\
\cline { 2 - 9 } & Mean & SD & Mean & SD & Mean & SD & Mean & SD \\
\hline \multirow{4}{*}{1} & 633.2 & 172.7 & 331.2 & 133.5 & 420.0 & 139.4 & 405.8 & 126.6 \\
\cline { 2 - 9 } & 631.2 & 170.3 & 361.0 & 185.5 & 417.3 & 130.8 & 400.3 & 126.8 \\
\cline { 2 - 9 } & 639.2 & 177.0 & 360.5 & 136.7 & 413.6 & 150.6 & 395.2 & 140.4 \\
\hline 2 & 739.4 & 140.8 & 426.0 & 119.6 & 456.5 & 107.3 & 436.5 & 103.8 \\
\cline { 2 - 9 } & 731.2 & 136.8 & 432.6 & 124.0 & 458.0 & 127.3 & 441.0 & 100.5 \\
\cline { 2 - 8 } & 756.0 & 156.6 & 432.6 & 127.4 & 452.5 & 111.3 & 437.3 & 105.3 \\
\hline 3 & 264.0 & 93.4 & 136.0 & 46.8 & 144.8 & 54.3 & 139.3 & 53.0 \\
\cline { 2 - 8 } & 260.4 & 94.4 & 135.5 & 47.1 & 143.3 & 56.8 & 140.0 & 51.0 \\
\cline { 2 - 8 } & 261.3 & 89.6 & 134.1 & 44.9 & 146.0 & 58.8 & 139.0 & 52.8 \\
\hline
\end{tabular}


End of Table 3

\begin{tabular}{|c|c|c|c|c|c|c|c|c|}
\hline \multirow{3}{*}{ Sample No } & \multicolumn{4}{|c|}{ "In the Air" } & \multicolumn{4}{c|}{ "In phantom" } \\
\cline { 2 - 9 } & \multicolumn{3}{|c|}{$300 \mathrm{~mA}$} & \multicolumn{3}{c|}{$300 \mathrm{~mA}$} \\
\cline { 2 - 9 } & \multicolumn{2}{|c|}{ FC17 } & \multicolumn{2}{|c|}{ FC03 } & \multicolumn{2}{c|}{ FC17 } & \multicolumn{2}{c|}{ FC03 } \\
\cline { 2 - 9 } & Mean & SD & Mean & SD & Mean & SD & Mean & SD \\
\hline \multirow{4}{*}{4} & 782.0 & 159.0 & 502.2 & 135.2 & 527.2 & 125.0 & 540.8 & 122.8 \\
\cline { 2 - 9 } & 781.0 & 158.0 & 502.5 & 136.0 & 527.5 & 124.5 & 541.0 & 123.0 \\
\cline { 2 - 9 } & 783.0 & 159.0 & 503.0 & 135.5 & 527.0 & 123.0 & 539.0 & 122.5 \\
\hline 5 & 802.0 & 196.4 & 499.0 & 163.4 & 554.6 & 141.0 & 561.2 & 141.8 \\
\cline { 2 - 9 } & 801.0 & 196.0 & 500.0 & 164.0 & 554.5 & 142.0 & 561.5 & 142.0 \\
\cline { 2 - 9 } & 800.0 & 197.0 & 498.0 & 163.0 & 555.0 & 141.5 & 562.0 & 141.0 \\
\hline \multirow{4}{*}{6} & 774.2 & 166.6 & 444.2 & 133.6 & 503.5 & 127.3 & 510.5 & 126.0 \\
\cline { 2 - 9 } & 774.0 & 167.0 & 444.0 & 134.0 & 504.0 & 127.5 & 510.0 & 125.0 \\
\cline { 2 - 9 } & 775.0 & 166.0 & 443.0 & 133.0 & 503.0 & 128.0 & 511.0 & 127.0 \\
\hline 7 & 190.0 & 135.5 & 101.0 & 79.5 & 100.0 & 69.8 & 99.8 & 65.0 \\
\cline { 2 - 9 } & 191.0 & 135.5 & 101.0 & 80.0 & 100.0 & 70.0 & 99.0 & 65.0 \\
\cline { 2 - 9 } & 190.0 & 136.0 & 102.0 & 79.0 & 99.0 & 69.0 & 100.0 & 66.0 \\
\hline \multirow{4}{*}{8} & 484.6 & 129.2 & 213.0 & 87.0 & 314.6 & 91.0 & 310.2 & 88.0 \\
\cline { 2 - 8 } & 485.0 & 129.0 & 214.0 & 87.0 & 315.0 & 91.0 & 310.0 & 88.0 \\
\cline { 2 - 8 } & 484.0 & 130.0 & 213.0 & 88.0 & 314.0 & 90.0 & 309.5 & 89.0 \\
\hline
\end{tabular}

The values in Tables 2 and 3 were analyzed using statistical methods. The task was to evaluate how strongly different convolution kernels, different tube current values, and also the beam-hardening affect the HU of the same samples.

The hypothesis about the normal distribution of the examined data from Table 2 using the Kolmogorov-Smirnov criterion was confirmed at $5 \%$ significance level. This allowed a further analysis using the parametric Student's t-test.

\section{3. "In the air"}

To test the hypothesis that there were no differences in Hounsfield units "in the air" for $40 \mathrm{~mA}$ and $300 \mathrm{~mA}$ tube current, the Student's t-test was used for paired observations. This hypothesis was confirmed at a significance level of $5 \%$ for both investigated convolution kernels (FC17 and FC03). The correlation coefficients between the corresponding data sets in the case of both kernels exceeded the value of 0.999 , which in this case also indicates the coincidence of the measurement results.

Application of the same criterion to test the hypothesis that the Hounsfield numbers "in the air" coincided for different kernels (FC17 and FC03) at a fixed tube current value $(40 \mathrm{~mA}$ and $300 \mathrm{~mA})$ showed a shift in the measurements at less than $0.001 \%$ significance level.

The determined x-ray density (HU) is higher for the FC 17 convolution kernel. This difference is caused by beam hardening correction applied in the FC03 convolution kernel (CT Manual Toshiba 14.1.5. P. 204). The effects are not described in detail.

Nevertheless, a high correlation was found between the samples for different kernels ( 0.963 in case of $40 \mathrm{~mA}$ tube current and 0.959 in case of $300 \mathrm{~mA}$ tube current), which indicates the presence of interdependencies. This was confirmed by the linear regression equations: 
For $40 \mathrm{~mA}$ tube current:

$$
H u_{F C 03}=0.66 * H u_{F C 17}, \quad R^{2}=0.978 .
$$

For $300 \mathrm{~mA}$ tube current:

$$
H u_{F C 03}=0.64 * H u_{F C 17}, \quad R^{2}=0.978
$$

The Chow test at a significance level of $5 \%$ showed the absence of structural shifts in two regressions for different tube current values, which indicates the coincidence of the dependencies.

It was shown that an increase in density does not always entail an increase in Hounsfield units for calibrated samples with mineral density corresponding to trabecular bone. This conclusion is valid for scans "in the air" processed with FC03 kernel for both tube currents (Fig. 5, Table 2). A nonlinear dependence was noted for mineral density values of 50-250 $\mathrm{mg} / \mathrm{ml}$. Correct interpretation of experimental data for a given density range is difficult.

In phantom (for the both FC03 and FC17 kernels) this effect was absent in the same way as in the air with FC17 kernel. The reason for this "paradoxical" dependence of Hounsfield units on volume mineral density is the calculated nature of HU.

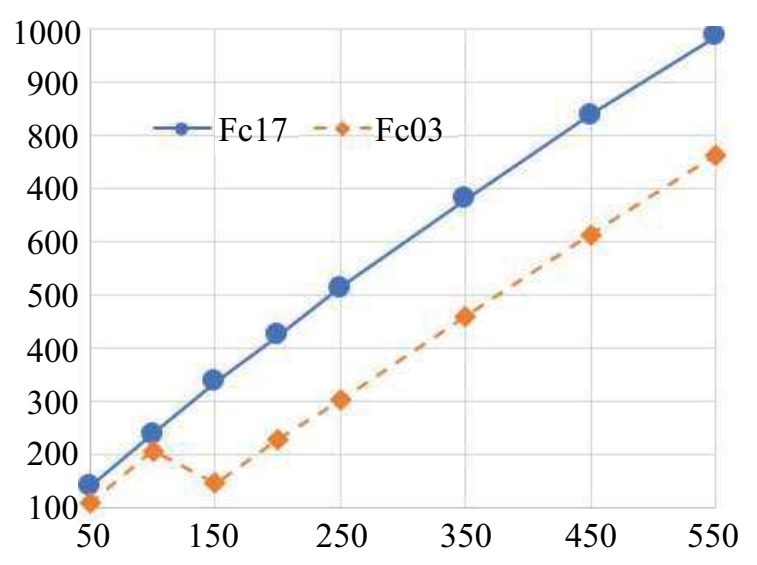

Fig 5. Hounsfield units' dependence (vertical) of $\mathrm{K}_{2} \mathrm{HPO}_{4}$ samples on their mineral density (horizontal $\mathrm{mg} / \mathrm{sm}^{3}$ ). Scanning "in the air", $300 \mathrm{~mA}$ (color online)

\section{4. "In phantom"}

Student's t-test was used for paired observations to test the hypothesis of coincidence of measurements made "in phantom' with different kernels (FC17 and FC03) at a fixed $300 \mathrm{~mA}$ tube current. There were no differences in measurements at $5 \%$ significance level. The value of the correlation coefficient was 0.999 .

\section{5. "In the air" versus "in phantom"}

Student's t-test for paired observations was used to test the hypothesis that the results of measurements performed "in the air" and "in phantom" for each kernel (FC17 and FC03) coincided at fixed $300 \mathrm{~mA}$ tube current.

A statistically significant difference in measurement results "in the air" and "in phantom" at significance levels of less than $0.001 \%$ was found for the FC17 kernel. It was shown that there were no differences in measurements "in the air" and "in phantom" at $5 \%$ significance level for the FC03 kernel.

The obtained regression dependences made it possible to recalculate $\mathrm{HU}$ of $\mathrm{K}_{2} \mathrm{HPO}_{4}$ samples from "in the air" experiments into $\mathrm{HU}$ of $\mathrm{K}_{2} \mathrm{HPO}_{4}$ "in the phantom" for both FC17 and FC03 kernels. Regression dependences are demonstrated in Fig. $6 a, b$. 

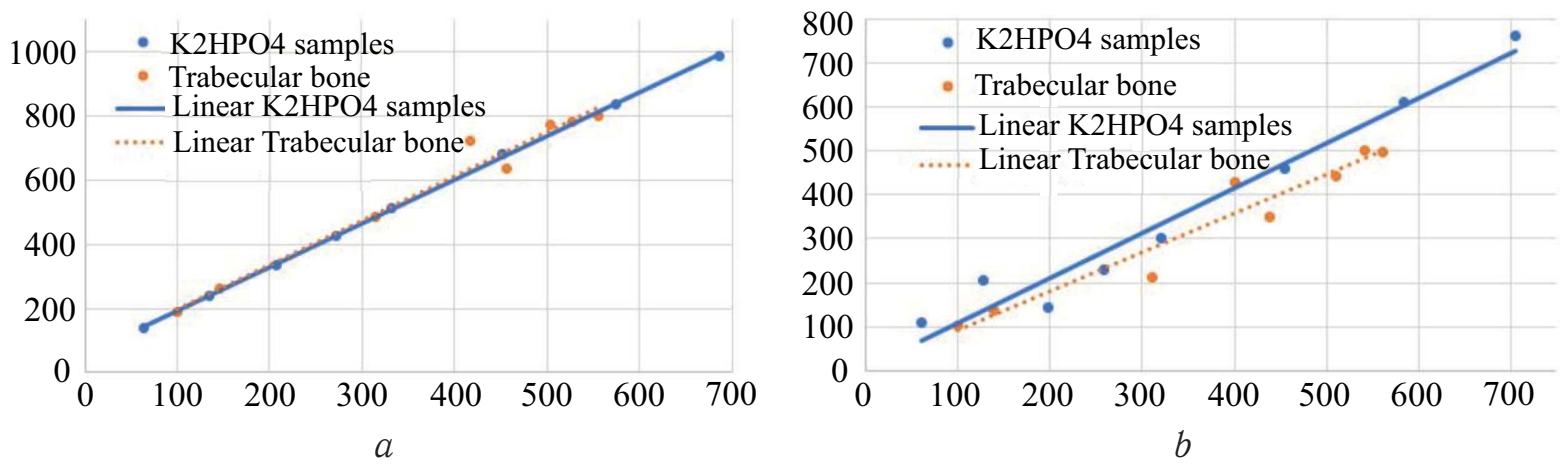

Fig. 6. Regression dependences of recalculation of $\mathrm{HU}$ from "in the air" (horizontal axis) to "in phantom" (vertical axis) for calibrated $\mathrm{K}_{2} \mathrm{HPO}_{4}$ samples and trabecular bone samples: $a-$ for FC17 kernel (solid line $y=0.7 * x-40.8, R^{2}=0.99$ is a linear regression for $\mathrm{K}_{2} \mathrm{HPO}_{4}$ samples, dotted line $y=0.7 * x-33.9, R^{2}=0.97$ is a linear regression for trabecular bone samples); $b$ - for FC03 kernel (solid line $y=1.0 * x+22.0, R^{2}=0.94$ is a linear regression for $\mathrm{K}_{2} \mathrm{HPO}_{4}$ samples, dotted line $y=0.9 * x+7.0, R^{2}=0.96$ is a linear regression for trabecular bone samples) (color online)

\section{DISCUSSION}

In this paper, it is shown that processing of $\mathrm{CT}$ images using discrete convolution matrix can significantly change them (Fig. $4 a, b, c$ ). This is very important for optimal visualization. Convolution kernels of CT scanners are much more complicated, since they can include the sequential use of several convolution algorithms. It should be understood that such processing can slightly shift the contours of the objects which is shown in Fig. 4, $c$.

Unfortunately, image conversion by convolution kernel is an irreversible operation. This means that even if one has the exact formula for direct image conversion, no algorithm allows restoring the original image. Moreover, manufacturers of CT scanners do not disclose the mathematical formulas of the convolution kernels and the conditions for their use.

This paper also investigated the influence of various effects and CT scanner settings on HUs of trabecular bone tissue samples and $\mathrm{K}_{2} \mathrm{HPO}_{4}$ samples with known mineral density. A series of scans were carried out on Toshiba CT with samples "in the air", that is, on the table of the CT scanner without taking into account the surrounding tissues, and "in phantom" that simulates human soft tissues.

In this work, the effect of FOV and slice thickness were not investigated, since it was previously shown [10] that a change in these parameters has practically no effect on $\mathrm{HU}$.

At the same time, these [10] and other authors [4] noted a significant dependence of the HU on the convolution kernel, as well as the presence or absence of the environment of the scanned samples; and the influence of the object geometry on its density, expressed in HU during CT scanning. It was associated with the beam-hardening effect and its adjustment during the image reconstruction [11].

In this work, it was shown that the tube current practically does not affect HU. Different convolution kernels give significantly different HUs when scanning "in the air»" of the same samples. At the same time, the absence of differences in measurements "in the air" and "in phantom" at a significance level of 5\% for FC03 kernel was shown, which confirms the fact that it was developed to correct "beam-hardening" effect [7]. 
However, at low mineral densities of the scanned samples, an ambiguous relationship was observed between HU and mineral density (Fig. 5). Such an ambiguity was not found for the FC17 kernel; therefore, we consider it more preferable and suitable for estimating BMD in comparison with the FC03 kernel under the conditions of the performed experimental work. This is important for acquiring phantom scan data from air scan data for bone samples.

The nonlinearity of this filter can be verified by qualitatively analyzing the dependence for FC17 in Fig. 5. At high concentrations, a slight underestimation of HU occurs. But this is enough for patients to record underestimated BMD values in comparison with conventional densitometry.

The beam-hardening effect significantly affects the $\mathrm{HU}$ and should be considered when evaluating BMD which could be seen from data in Tables 2 and 3 . The difference in $\mathrm{HU}$ for FC03 and FC17 kernels for the same samples when scanning "in the air" reached $130 \%$ (on average about $56 \%$ ) for $\mathrm{K}_{2} \mathrm{HPO}_{4}$ samples and up to $128 \%$ (on average about $81 \%$ ) for trabecular bone samples tissue.

The difference in $\mathrm{HU}$ in case of FC17 kernel for the same samples when scanning "in the air" and "in the phantom" reached $120 \%$ (on average about $65 \%$ ) for $\mathrm{K}_{2} \mathrm{HPO}_{4}$ samples and up to $90 \%$ (on average about $61 \%$ ) for samples of sponge bone tissue. At the same time, the character of the dependence of HU on mineral density was completely preserved (Fig. 5). This made it possible to obtain an almost "ideal" regression dependence for a given filter when comparing scans "in the air" and phantom modes (Fig. 6 a).

Nevertheless, the regression dependences in Fig. $6 a, b$ make it possible to recalculate the HU from the "in the air" experiments into HU for the same samples considering the surrounding tissues ("in phantom"). The dependences for calibrated samples and trabecular bone tissue samples for FC17 kernel practically coincide, which is confirmed by the same angles of inclination of these lines. For FC03 kernel, the line angles for calibrated and trabecular bone samples differ insignificantly. It is more efficient to use FC17 kernel, which does not have pronounced nonlinearity in the initial portion of the curve of the dependence of HU on the mineral density.

The data obtained during phantom modeling allow scanning bone tissue "in the air" and recalculating the obtained data into mineral density, or into Hounsfield units "in phantom" imitating a patient. For these purposes, the FC17 convolution kernel is more suitable. This greatly simplifies the scanning procedure.

\section{CONCLUSION}

In this paper, it was shown that tube current value does not significantly affect HU during CT scanning. It was revealed that different convolution kernels of a Canon (Toshiba) CT scanner give significantly different HU when scanning "in the air" for the same bone tissue samples and calibrated samples with known mineral density. It has been confirmed that "beam-hardening" effect significantly affects the HU and should be considered when evaluating the BMD. We did not reveal differences in measurements "in the air" and "in the phantom" at a significance level of 5\% for the FC03 kernel, which confirms the fact that it was developed to correct the effect of "beam-hardening". An ambiguous relationship was found between the HU and the mineral density for the FC03 kernel when scanning samples with a low mineral density. Therefore, we consider the FC17 convolution kernel (in comparison with FC03) of the Toshiba CT scanner to be more preferable and suitable for assessing BMD under the given experimental condi- 
tions. Regression dependencies were obtained for recalculation of HU from experiments "in the air" to HU of the same samples considering the surrounding tissues.

Acknowledgements: This work was supported by the Russian Foundation for Advanced Research.

\section{References}

1. Patel S. P., Lee J. J., Hecht G. G., Holcombe S. A., Wang S. C., Goulet G. A. Normative Vertebral Hounsfield Unit Values and Correlation with Bone Mineral Density. J Clin Exp Orthop., 2016, vol. 2, no. 14. DOI: https://doi.org/10.4172/2471-8416.100014

2. Kim K. J., Kim D. H., Lee J. I., Choi B. K., Han I. H., Nam K. H. Hounsfield Units on Lumbar Computed Tomography for Predicting Regional Bone Mineral Density. Open Med., 2019, vol. 14, iss. 1, pp. 545-551. DOI: https://doi.org/10.1515/med-2019-0061

3. Khan S. N., Warkhedkar R. M., Shyam A. K. Analysis of Hounsfield Unit of Human Bones for Strength Evaluation. Procedia Materials Science, 2014, vol. 6, pp. 512-519. DOI: https://doi.org/10.1016/j.mspro.2014.07.065

4. Giambini H., Dragomir-Daescu D., Huddleston P. M., Camp J. J., An K. N., Nassr A. The Effect of Quantitative Computed Tomography Acquisition Protocols on Bone Mineral Density Estimation. J Biomech Eng., 2015, vol. 137, no. 11, p. 114502. DOI: https://doi.org/10.1115/1.4031572

5. Pickhardt P. J., Bodeen G., Brett A., Brown J. K., Binkley N. Comparison of femoral neck BMD evaluation obtained using lunar DXA and QCT with asynchronous calibration from CT colonography. J Clin Densitom, 2015, vol. 18, no. 1, pp. 5-12. DOI: https://doi.org/10.1016/j.jocd.2014.03.002

6. Brown J. K., Timm W., Bodeen G., Chason A., Perry M., Vernacchia F., Delournett R. Asynchronously Calibrated Quantitative Bone Densitometry. J Clin Densitom, 2017, vol. 20, no. 2, pp. 216-225. DOI: https://doi.org/10.1016/j.jocd.2015.11.001

7. Andersen H. K., Jensen K., Berstad A. E., Aalokken T. M., Kristiansen J., von Gohren Edwin B., Hagen G., Martinsen A. C. Choosing the best reconstruction technique in abdominal computed tomography: a systematic approach. J Comput Assist Tomogr, 2014, vol. 38, no. 6, pp. 853-858. DOI: https://doi.org/10.1097/RCT.0000000000000139

8. Michalski A. S., Edwards W. B., Boyd S. K. The Influence of Reconstruction Kernel on Bone Mineral and Strength Estimates Using Quantitative Computed Tomography and Finite Element Analysis. J Clin Densitom, 2019, vol. 22, no. 2, pp. 219-228. DOI: https://doi.org/10.1016/j.jocd.2017.09.001

9. Birnbaum B. A., Hindman N., Lee J., Babb J. S. Multi-detector row CT attenuation measurements: assessment of intra- and interscanner variability with an anthropomorphic body CT phantom. Radiology, 2007, vol. 242, no. 1, pp. 109-119. DOI: https://doi.org/10.1148/radiol.2421052066

10. Free J., Eggermont F., Derikx L., van Leeuwen R., van der Linden Y., Jansen W., Raaijmakers E., Tanck E., Kaatee R. The effect of different CT scanners, scan parameters and scanning setup on Hounsfield units and calibrated bone density: a phantom study. Biomed. Phys. Eng. Express, 2018, vol. 4, no. 5, p. 055013. DOI: https://doi.org/10.1088/20571976/aad66a

11. Gromov A. I., Petraikin A. V., Kulberg N. S., Kim S. Yu., Morozov S. P., Sergunova K. A., Usanov M. S. The Problem of X-Ray Attenuation Estimation Accuracy in Multislice Computed Tomography. Medical Visualization, 2016, no. 6, pp. 133-142 (in Russian).

12. Crookshank M., Ploeg H.-L., Ellis R., Macintyre N. J. Repeatable calibration of Hounsfield units to mineral density and effect of scanning medium. Advances in Biomechanics and Applications, 2013, vol. 1, no. 1, pp. 015-022. DOI: http://dx.doi.org/10.12989/aba.2013.1.1.015

13. Witt R. M., Cameronand J. R. Improved bone standard containing dipotassium hydro- 
gen phosphate solution for the intercomparison of different transmission bone scanning systems. Technical Report. 1970. NTIS Issue Number 197112. 6 p.

14. Morozov S. P., Sergunova K. A., Petryaykin A. V., Semenov D. S., Petryaykin F. A., Akhmad E. S., Nizovtsova L. A., Vladzimirsky A. V. Phantom device for testing x-ray methods of osteodensitometry. Utility Model Patent 186961. RF. No. 2018125297; declared 10.07.2018; published 11.02.2019. Bull. no. 5. 11 p. (in Russian).

15. Glantz S. A. Primer of biostatistics. Seventh Edition. New York, McGraw-Hill, 2011. $320 \mathrm{p}$.

16. Kobzar A. I. Applied Mathematical Statistics. For Engineers and Scientists. Moscow, Fizmatlit, 2006. 816 p. (in Russian).

Cite this article as:

Ivanov D. V., Kirillova I. V., Kossovich L. Yu., Bessonov L. V., Petraikin A. V., Dol A. V., Ahmad E. S., Morozov S. P., Vladzymyrskyy A. V., Sergunova K. A., Kharlamov A. V. Influence of Convolution Kernel and Beam-Hardening Effect on the Assessment of Trabecular Bone Mineral Density Using Quantitative Computed Tomography. Izv. Saratov Univ. (N. S.), Ser. Math. Mech. Inform., 2020, vol. 20, iss. 2, pp. 205-219. DOI: https://doi.org/10.18500/18169791-2020-20-2-205-219

УДК 539.3/617.547

\title{
Влияние конволюционных ядер и эфрфекта «упрочнения луча» на оценку минеральной плотности губчатой костной ткани с использованием количественной компьютерной томографии
}

\author{
Д. В. Иванов, И. В. Кириллова, Л. Ю. Коссович, Л. В. Бессонов, \\ А. В. Петряйкин, А. В. Доль, Е. С. Ахмад, С. П. Морозов,
} А. В. Владзимирский, К. А. Сергунова, А. В. Харламов

Иванов Дмитрий Валерьевич, кандидат фризико-математических наук, ведущий научный сотрудник лаборатории систем поддержки принятия врачебных решений, Образовательно-научный институт наноструктур и биосистем, Саратовский национальный исследовательский государственный университет имени Н. Г. Чернышевского, Россия, 410012, г. Саратов, ул. Астраханская, д. 83, ivanovdv@gmail.com

Кириллова Ирина Васильевна, кандидат фризико-математических наук, заведующий лабораторией систем поддержки принятия врачебных решений, Образовательно-научный институт наноструктур и биосистем, Саратовский национальный исследовательский государственный университет имени Н. Г. Чернышевского, Россия, 410012, г. Саратов, ул. Астраханская, д. 83, nano-bio@info.sgu.ru

Коссович Леонид Юрьевич, доктор фризико-математических наук, президент, Саратовский национальный исследовательский государственный университет имени Н. Г. Чернышевского, Россия, 410012, г. Саратов, ул. Астраханская, д. 83, president@info.sgu.ru

Бессонов Леонид Валентинович, кандидат фризико-математических наук, старший научный сотрудник лаборатории систем поддержки принятия врачебных решений, Образовательно-научный институт наноструктур и биосистем, Саратовский национальный исследовательский государственный университет имени Н. Г. Чернышевского, Россия, 410012, г. Саратов, ул. Астраханская, д. 83, bessonov@sgu.ru 
Петряйкин Алексей Владимирович, кандидат медицинских наук, доцент, ведущий научный сотрудник отдела разработки средств контроля и технического мониторинга, Научно-практический клинический центр диагностики и телемедицинских технологий Департамента здравоохранения города Москвы, Россия, 109029, г. Москва, ул. Средняя Калитниковская, д. 28, стр. 1, alexeypetraikin@gmail.com

Доль Александр Викторович, кандидат фризико-математических наук, старший научный сотрудник лаборатории систем поддержки принятия врачебных решений, Образовательно-научный институт наноструктур и биосистем, Саратовский национальный исследовательский государственный университет имени Н. Г. Чернышевского, Россия, 410012, г. Саратов, ул. Астраханская, д. 83, dzero@pisem.net

Ахмад Екатерина Сергеевна, научный сотрудник отдела разработки средств контроля и технического мониторинга, Научно-практический клинический центр диагностики и телемедицинских технологий Департамента здравоохранения города Москвы, Россия, 109029, г. Москва, ул. Средняя Калитниковская, д. 28, стр. 1, e.ahmad@npcmr.ru

Морозов Сергей Павлович, доктор медицинских наук, профрессор, директор, Научно-практический клинический центр диагностики и телемедицинских технологий Департамента здравоохранения города Москвы, Россия, 109029, г. Москва, ул. Средняя Калитниковская, д. 28, стр.1, npcmr@zdrav.mos.ru

Владзимирский Антон Вячеславович, доктор медицинских наук, заместитель директора по научной работе, Научно-практический клинический центр диагностики и телемедицинских технологий Департамента здравоохранения города Москвы, Россия, 109029, г. Москва, ул. Средняя Калитниковская, д. 28, стр. 1, info@npcmr.ru

Сергунова Кристина Анатольевна, руководитель отдела разработки средств контроля и технического мониторинга, Научно-практический клинический центр диагностики и телемедицинских технологий Департамента здравоохранения города Москвы, Россия, 109029, г. Москва, ул. Средняя Калитниковская, д. 28, стр. 1, sergunova@rpcmr.org.ru

Харламов Александр Владимирович, кандидат фризико-математических наук, ведущий научный сотрудник лаборатории систем поддержки принятия врачебных решений, Образовательно-научный институт наноструктур и биосистем, Саратовский национальный исследовательский государственный университет имени Н. Г. Чернышевского, Россия, 410012, г. Саратов, ул. Астраханская, д. 83, harlamovav@info.sgu.ru

Для оценки минеральной плотности и прочности костных тканей наряду с денситометрией применяется количественная компьютерная томограсрия. «Сырые» данные, полученные при компьютерной томограсрии, преобразуются программным обеспечением томограсра посредством сверточных (конволюционных) ядер. Известно, что при применении конволюционных ядер может существенно изменяться плотность тканей, выраженная в единицах Хаунсфрилда. Описан эфрфрект «упрочнения луча» (beam-hardening effect): при прохождении рентгеновского луча через объект происходит поглощение фоттонов рентгеновского излучения с более низкой энергией. Поэтому сканирование объектов «на воздухе» без окружения мягких тканей тела человека дает искаженные числа Хаунссрилда относительно их реальных значений. Данная работа нацелена на то, чтобы оценить влияние различных конволюционных ядер, эффректа «упрочнения луча», а также других параметров настройки компьютерного томографра на единицы Хаунсфилда губчатой костной ткани головок бедра и калиброванных образцов водного раствора гидроортофросфата калия с известной минеральной плотностью. Образцы губчатой костной ткани головок бедра и калиброванные образцы водного раствора гидроортосроссрата калия с известной минеральной плотностью сканировали на компью- 
терном томографре Toshiba Aquilion 64. Сканирование образцов осуществляли в различных режимах: при разном токе, «на воздухе» и внутри калибровочного франтома. При этом анализировались результирующие изображения, обработанные конволюционными ядрами FC17 и FC03. Было показано, что величина тока практически не влияет на числа Хаунссрилда. Различные конволюционные ядра демонстрируют существенно разные числа Хаунссрилда при сканировании «на воздухе» одних и тех же образцов. Эфрфект «beam hardening» существенно влияет на числа Хаунссрилда и должен учитываться при оценке минеральной плотности костной ткани. Не выявлены различия в измерениях «на воздухе» и в франтоме на уровне значимости $5 \%$ для ядра FC03, что подтверждает тот фракт, что оно предназначено для корректировки эфрфекта «beam-hardening». Однако при малых минеральных плотностях сканируемых образцов отмечается неоднозначная зависимость между числами Хаунсфрилда и минеральной плотностью для ядра FC03. Ядро FC17 считаем более предпочтительным и пригодным для оценки минеральной плотности костной ткани с учетом предварительной калибровки с помощью франтома для широкого диапазона заданных минеральных плотностей. Получены регрессионные зависимости для пересчета чисел Хаунссрилда из экспериментов «на воздухе» в числа Хаунсфилда тех же образцов с учетом окружающих тканей (в франтоме).

Ключевые слова: компьютерная томограсрия, количественная компьютерная томографрия, минеральная плотность костной ткани, число Хаунсфрилда, конволюционное ядро.

Поступила в редакцию: 15.12.2019 / Принята: 22.01.2020 / Опубликована: 01.06.2020

Статья опубликована на условиях лицензии Creative Commons Attribution License (CC-BY 4.0)

Благодарности. Работа выполнена при финансовой поддержке Фонда перспективных исследований.

\section{Образец для цитирования:}

Ivanov D. V., Kirillova I. V., Kossovich L. Yu., Bessonov L. V., Petraikin A. V., Dol A. V., Ahmad E. S., Morozov S. P., Vladzymyrskyy A. V., Sergunova K. A., Kharlamov A. V. Influence of Convolution Kernel and Beam-Hardening Effect on the Assessment of Trabecular Bone Mineral Density Using Quantitative Computed Tomography [Нванов Д. В., Кириллова И. В., Коссович Л. Ю., Бессонов Л. В., Петряйкин А. В., Доль А. В., Ахмад Е. С., Морозов С. П., Владзимирский $A$. В., Сергунова K. А., Харламов $A$. В. Влияние конволюционных ядер и эффекта «упрочнения луча» на оценку минеральной плотности губчатой костной ткани с использованием количественной компьютерной томографии] // Изв. Сарат. ун-та. Нов. сер. Сер. Математика. Механика. Информатика. 2020. Т. 20, вып. 2. С. 205-219. DOI: https://doi.org/10.18500/1816-9791-2020-20-2-205-219 